\title{
Assessment of climate change on the future water levels of the Iberá Wetlands, Argentina, during the $21^{\text {st }}$ century
}

\author{
Natalia B. Montroull ${ }^{1}$, Ramiro I. Saurral ${ }^{1,2}$, Inés A. Camilloni ${ }^{1,2}$, Rafael Grimson ${ }^{3,4}$ and \\ Pablo Vasquez ${ }^{3}$ \\ ${ }^{1}$ Centro de Investigaciones del Mar y la Atmósfera (CIMA, UBA-CONICET), UMI- \\ IFAECI/CNRS \\ 2 Departamento de Ciencias de la Atmósfera y los Océanos (DCAO, FCEN-UBA) \\ ${ }^{3}$ Departamento de Matemática, (FCEN-UBA), Buenos Aires, Argentina. \\ ${ }^{4}$ Instituto de Investigaciones Matemáticas Luis A. Santaló (CONICET-UBA), Buenos \\ Aires, Argentina.
}

Corresponding author:

Natalia B. Montroull

Centro de Investigaciones del Mary y la Atmósfera

Int. Güiraldes 2160, Ciudad Universitaria, Pab. 2 (C1428EGA)

Telephone/fax number: +54-11-4576-3398

Buenos Aires

Argentina

Email: nmontroull@cima.fcen.uba.ar

saurral@cima.fcen.uba.ar

ines@cima.fcen.uba.ar

rgrimson@dm.uba.ar

pevasquez@gmail.com

Submitted: February 2013

Revised: June 2013

CLARIS-LPB Special Issue 


\begin{abstract}
The Iberá wetlands, located in La Plata Basin, is a fragile ecosystem habitat of several species of flora and fauna and it also constitutes one of the largest inland freshwater of the world. In this study the hydroclimatologic response to projected climatic changes in the Iberá wetlands is assessed. Bias corrected temperature and precipitation data from four Regional Climate Models (RCMs) developed for the CLARIS-LPB project were used to drive the calibrated Variable Infiltration Capacity (VIC) hydrological model for different time slices. Derived future scenarios consist on changes in temperature, precipitation and water level of the Iberá Lake for the periods 2021-2040 and 20712090 with respect to present. All RCMs are consistent in predicting a warming for the near future $\left(0-2^{\circ} \mathrm{C}\right)$ and also to the end of the century $\left(1.5-4.5^{\circ} \mathrm{C}\right)$ in the study region, but differ in the sign and percentage of precipitation changes. ViC modeling results suggest that the Iberá Lake level could increase in the $21^{\text {st }}$ century and that this increment would be higher in the summer months. Nevertheless, the projected $10 \mathrm{~cm}$ of water level increase could be not so relevant as it is of the same order of magnitude than the observed interdecadal variability of the system.
\end{abstract}

Keywords: Wetland hydrology simulation, climate change, Iberá Wetlands, VIC hydrologic model. 


\section{Introduction}

The La Plata Basin (LPB) in southeastern South America hosts the Iberá wetlands (or Esteros del Iberá in Spanish), one of the largest continuous freshwater wetland in South America. Due to its high level of conservation and biodiversity, it was included in the Ramsar Convention list of the most important wetland of the world. Southeastern South America is an area where climate change is particularly evident, with a remarkable increment in precipitation (Giorgi 2002; Barros et al. 2008), and positive trends in river discharges since the 1970s (Bischoff et al. 2000, Camilloni and Barros 2003, Barros et al. 2004). Climate variability and change could modify the Iberá wetlands hydrological conditions and consequently affect its biodiversity (Ferrati et al. 2005, Solomon et al. 2007). It is therefore essential to advance in understanding the hydrological variations of this wetland as a consequence of climate change in order to design better management practices and appropriate adaptation strategies for the conservation of this regional ecosystem considering that small changes in water levels may produce dramatic changes in the wetland biotic components and ecological functioning.

The most popular tool to understand and project the climate variability and change are the Global Climate Models (GCMs). Frequently, future climatic scenarios derived from GCMs are used in combination with hydrological models to determine the hydrometeorological impacts due to climate changes at a basin level. Nevertheless, many authors have analyzed the skill of GCMs (Camilloni and Bidegain 2005, Vera et al. 2006, Boulanger et al. 2007, Silvestri and Vera 2008, Vera et al. 2009, Gulizia et al. 2012) and they all show that GCMs still have difficulties in representing the current climate over South America. Moreover, their coarse resolution (typically, $2.5^{\circ} \times 2.5^{\circ}$ ) makes almost impossible to use meteorological information directly from GCMs in the hydrological models without bridging the gap between the resolution of these climate models and local scales such as basins through downscaling techniques. The use of Regional Climate Models (RCMs) to bridge this gap has recently become more popular as a basis for hydrological studies (Fowler et al. 2007, Teutschbein and Seibert 2012). RCMs transfer the large-scale information provided by GCMs into smaller scales which are closer to a catchment level. However, RCMs spatial resolution still exceeds the scale of a watershed such as the Iberá Wetlands. Consequently, to reduce the uncertainties associated to the systematic errors of climate models and generate high resolution scenarios, many authors propose different methods to produce bias corrected meteorological information for hydrological impact studies (Hay et al. 2002, 
Wood et al. 2002, 2004, Vidal and Wade 2007, van Roosmalen et al. 2010, Piani and Haerter 2012).

The objective of this study is to derive hydroclimatic scenarios for the Iberá wetlands for the rest of the $21^{\text {st }}$ century. To achieve this goal, the ability of a set of $\mathrm{RCMs}$ to represent regional temperature and precipitation patterns is evaluated. Bias corrected RCMs outputs are used to develop projections of future changes of temperature and precipitation for two time slices (2021-2040) and (2071-2090) under the A1B emission scenario (see Solomon et al. 2007 for further details on the scenarios). Finally, projections on water level changes of the Iberá system for the same time slices are obtained using the bias corrected RCMs data as input of a hydrologic model.

\section{Data and Methodology}

\subsection{Region of study}

The Iberá wetlands are located in the province of Corrientes in the northeast end of Argentina, between $27^{\circ} 30^{\prime} \mathrm{S}$ and $29^{\circ} \mathrm{S}$, and 56. $25^{\prime} \mathrm{W}$ and 58 $\mathrm{W}$ (Figure 1). The climate of this region is subtropical, with seasonal average temperatures that vary between $26^{\circ} \mathrm{C}$ in summer and $16^{\circ} \mathrm{C}$ during winter and a precipitation regime with two maxima (April and December) and an absolute minimum in August. Iberá constitutes one of the largest inland freshwater wetlands in South America with an area of approximately 12,000 km² (Neiff 1997, Giraut et al. 2009). Because of its small slope, the water flows very slowly trough the region and leads to a hydrologic balance that is predominantly vertical. The system drains into the Corriente River which finally contributes to the Paraná River. The annual mean flow of the Corriente River is 332 $\mathrm{m}^{3} / \mathrm{s}$ at Paso Lucero gauging station (Figure 1 ) and its annual cycle shows a onemonth lag with rainfall with maxima, in May and in January and an absolute minimum of $189 \mathrm{~m}^{3} / \mathrm{s}$ in September.

The Iberá region comprises a complex system of marshes that are interconnected with large shallow lakes. One of the most important is the Iberá Lake

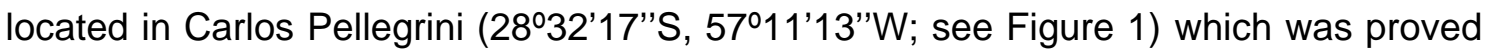
to be a good estimator of the level of the whole Iberá system (Cardinali and Chamorro 2002). Figure 2 shows the annual mean Iberá Lake level for the period 1929-2011. The average level for this period is $1.82 \mathrm{~m}$ with an interdecadal variability of $0.14 \mathrm{~m}$ derived from the 11-year running mean. Both Corriente River flows and Iberá Lake level data were taken from the Integrated Hydrological Database of Argentina. 


\subsection{The Hydrology Model}

The Variable Infiltration Capacity (VIC) hydrology model (Liang et al. 1994,1996, Bowling and Lettenmaier 2010, Mishra et al. 2010) version 4.1.2 was used in order to assess the future water balance of the Iberá wetlands due to climate change. VIC is a grid-based hydrologic model that solves both water and energy balances in each of the cells in which the catchment is divided. Input data for VIC include basin topography, land cover, soil properties, and meteorological data. The model has been successfully calibrated and applied over a large number of basins all over the globe, including La Plata basin (Saurral et al. 2008, 2013, Su and Lettenmaier 2009, Saurral 2010) and the Iberá wetlands (Montroull et al.2013, Grimson et al. 2013).

In order to deal with more complicated hydrological processes, VIC was updated a number of times since it was created in 1992 (Wood et al. 1992). The most recent version (VIC 4.1.2) has the ability to simulate the effect of lakes and wetlands within a portion of a grid cell. The lake/wetland tile contains a body of permanent open water whose areal extent is allowed to change in response to the water balance, which constitutes the seasonally flooded area or wetland (Bowling and Lettenmaier 2010, Gao et al. 2011). In the VIC model, the bathymetry of a lake/wetland is represented by a variable depth-area $(A(z))$ relationship. When the lake shrinks a portion of wetland vegetation emerge and when the lake level rises above a specific threshold $(M d)$, water flows into the channel network as flow over a broad-crested weir, calculated as a function of the lake's depth. One of the limitations of the model is that it only simulates lakes that receive all of thei inflows from within the same grid, therefore, we choose to simulate the Iberá system as a single grid cell of $14,000 \mathrm{~km}^{2}$ where $85 \%$ was estimated to be covered by lakes and wetlands $\left(12,000 \mathrm{~km}^{2}\right)$ using satellite imagery over the region.

The calibration of the model for the study region was done by adjusting soil and lake parameters and obtaining the best Nash-Sutcliffe efficiency coefficient (NSE, Nash and Sutcliffe 1970) for the Iberá Lake daily level for the period 1990-1997. The soil variables involved in the calibration process were the infiltration parameter $b_{i}$, the maximum velocity of baseflow Dsmax, the fraction of the Dsmax parameter at which non-linear baseflow occurs $D s$, the fraction of maximum soil moisture where non-linear baseflow occurs $W s$ and the thickness of the second and third soil layers $\left(D_{2}\right.$ and $\left.D_{3}\right)$. Regarding the lake model, the channel width fraction $f$ and the minimum depth for the 
lake channel output $M d$ were adjusted for the Iberá wetlands. The meteorological data used to force the model for the calibration consisted of daily precipitation, minimum and maximum temperature and wind speed obtained from the National Weather Service of Argentina, Agricultural Technology National Institute and CLARIS-LPB European-South American Project databases. Soil type information was obtained from the 5-min Global Soil Data Task dataset (Distributed Active Archive Center 2000) and the landcover information from the Univertsity of Maryland's 1-km Global Land Cover dataset (Hansen et al. 2000). Since the Iberá wetlands were modeled as a single grid cell, the meteorological, landcover and soil information was spatially averaged over the study area. More details of the model calibration and validation for an independent period (1997-2012) can be found in Grimson et. al. 2013. The NSE coefficient obtained for the period of calibration was 0.554 , which indicates an acceptable performance of the model considering the lower limit of 0.5 proposed by Santhi et al. (2001) for a good model performance. Figure 3 shows the observed and simulated with observed meteorological data daily level of the Iberá Lake at Carlos Pellegrini for 1991-2000. The NSE for this period is 0.47 and the correlation crefficient between the two series is 0.73 . These statistical results show that the VIC model has good performance not only for the calibration period but also for 1991-2000 considered as baseline to estimate future scenarios of Iberá Lake level changes as a result of increased atmospheric greenhouse gases concentration.

\subsection{RCM Data \& Bias correction Methodology}

The calibrated VIC model was forced with data from four RCMs generated within the CLARIS-LPB project (http://www.claris-eu.org) in order to simulate the present and future water balances of the Iberá wetlands. The RCMs used in this paper were the Rossby Centre RCM version 3.5 (RCA), (Kjellström et al. 2005, Samuelsson et al. 2006), the Prognostic at the Mesoscale version 2.4 (PROMES), (Sanchez et al. 2007, Dominguez et al. 2010), the ICTP Regional Climate Model version 3 (RegCM3), (Pal et al. 2007, da Rocha et al. 2009) and the Modele de Circulation Generale du LMD version 4 (LMDZ) (Li 1999, Hourdin et al. 2006) for the present climate and for 20212040 and 2071-2090 for future climate projections considering the A1B emission scenario. Present climate was considered as the period 1991-2000 for all the RCMs except for RegCM3 where the period used was 1981-1990 given that no information on the period 1991-2000 was available for that model. The hydrological projections were made under the assumption that vegetation and the geomorphology of the Iberá 
wetlands will remain unchanged as there are no scenarios of possible vegetation changes available for this region.

Both GCMs and RCMs are characterized by systematic errors in the representation of the atmospheric circulation and related variables. In this study, systematic biases in temperature and precipitation were removed by applying the "quantile-based mapping" bias correction method to the monthly data (Wood et al., 2002; Saurral, 2010). This methodology consists in constraining the distributions of these variables produced by the RCM to the observed climatology for a target period. The correction factors were calculated for the 1981-1990 decade and verified for the 1991-2000 period, for those models that had both periods. In the case of RegCM3 the correction factors were calculated and applied to the same period(1981-1990). The observational dataset used for application of the bias correction procedure for both temperature and precipitation was CRU v3.1 (Mitchell and Jones, 2005), which has a spatial resolution of $0.5^{\circ}$ lat $\times 0.5^{\circ}$ lon. All RCMs outputs were interpolated to the same grid as the observational dataset to make comparison possible. In order to make simulations with the VIC model, the bias corrected and raw RCMs outputs were spatially averaged over the Iberá area in order to obtain single meteorological data series for each variable.

\section{Results and Discussion}

\subsection{RCMs representation of the present climate for the Iberá Wetland region}

The annual and seasonal (December-January-February, DJF and June-JulyAugust, JJA) precipitation and mean temperature fields for the Iberá region as modeled by each RCM, along with the observed data for the present climate period are presented in Figures 4 and 5 respectively. The observed precipitation field shows a gradient with a maximum to the northeast of the domain and a minimum to the southwest, which are well captured by RegCM3, PROMES and LMDZ models. In general, all RCMs have a drier climatology than the one depicted by the observations. The only exception is the LMDZ model that has rainfall values larger than the observed ones during DJF. In the austral winter (JJA) CRU shows a very marked gradient with precipitation rates of $20 \mathrm{~mm} / \mathrm{month}$ to the west of the region and over $100 \mathrm{~mm} / \mathrm{month}$ to the east. Although all RCMs outline this gradient, none can capture its magnitude (Figure 4). In terms of temperature, all RCMs are somewhat warmer than the observations both annually and seasonally. The observed annual mean temperature 
ranges from $20^{\circ} \mathrm{C}$ at the south end of the basin to $22^{\circ} \mathrm{C}$ at the north end. However, modeled values vary from $21^{\circ} \mathrm{C}$ for RegCM3 to $25^{\circ} \mathrm{C}$ for PROMES for the whole basin. In the austral summer (DJF), the observed temperatures are mostly uniform in the Iberá region $\left(25-26^{\circ} \mathrm{C}\right)$ and the differences with the modeled temperatures are from $2^{\circ} \mathrm{C}$ for RCA up to $7^{\circ} \mathrm{C}$ for PROMES. In JJA differences are lower $\left(2^{\circ}-5^{\circ} \mathrm{C}\right)$ and RegCM3 shows even a colder climatology than the observed one.

Biases in the modeled vs. observed climatology are of special interest when using meteorological information from RCM as input data for hydrological models. The requirement of removing errors of climate models prior to their use in impact models is widely discuss in many papers (e.g. Vidal and Wade 2007, 2008, 2009, Quintana Seguí et al. 2010, Teutschbein and Seibert 2012, Piani and Hâerter 2012). In this study we evaluate the relative performance of the models before and after the application of a bias correction method by means of the Normalized Root Mean Square Error (NRMSE) (Eq.1),

$$
N R M S E=\frac{\sqrt{\frac{\sum_{i=1}^{N}\left(\overline{x_{M r}}-\overline{x_{O B} S v^{2}}\right.}{N}}}{\left(x_{M A X}-x_{M I N}\right)}
$$

where $\bar{X}_{M i}$ and $\bar{X}_{O B S i}$ are respectively the mean values of a meteorological variable derived from the model $M$ and the observations (OBS) in the grid point $i$ for the period 1991-2000. $X_{M A X}$ and $X_{M I N}$ correspond to the maximum and minimum value of the observations for the whole period. The mean values of observed precipitation and temperature for the Iberá region for the period 1991-2000 are summarized in Table 1. Figure 6 shows the NRMSE values for the bias corrected and uncorrected precipitation and temperature data for the Iberá area. Results for the annual precipitation indicate that the corrected data has, as expected, a better performance than the uncorrected data. In DJF, bias corrected models present overall lower NRMSE values, and only the LMDZ model does not present a clear improvement of the summer precipitation respect to the observed values. However, this RCM is the only one that has a better skill in JJA when considering the corrected data while the other three models present no improvement at all. On the other hand, temperature representation in the Iberá region is always better estimated when the correction is applied and the NRMSE values are below 0.5 both for the annual and seasonal averages.

\subsection{Future climate and hydrological projections}


Future daily precipitation and maximum and minimum temperatures, as simulated by the four RCMs, were bias corrected using the correction factors derived in the 19811990 decade and used as forcing data to simulate future hydrological conditions for the Esteros del Iberá. Figure 7 shows the differences between two future time slices (20212040 and 2071-2090) and the validation period for precipitation, temperature and lake water level in the wetland region.

Differences in precipitation between the near future (2021-2040) and the present climate show a great dispersion among the models, especially in the austral winter months. For instance, PROMES has little or no variation in precipitation compared to 1991-2000 period, but LMDZ has a negative difference in DJF and an increment of more than $100 \%$ in JJA. On the contrary, RCA shows a decrease in precipitation in the winter of about $20 \%$. When rainfall is considered annually, all models show an increase between 10 and 40\% (about $13 \mathrm{~mm} /$ day to $51 \mathrm{~mm} /$ day). Annual temperature differences are of about $1-1.5^{\circ} \mathrm{C}$ for almost all models except RCA, which predicts no variations in temperature for the region. Summer projections shows the same pattern of warming between 1.5 and $2^{\circ} \mathrm{C}$ in most models, only RCA shows a slightly decrease in temperature. Winter values in the Iberá region are likely to increase between $0.5^{\circ} \mathrm{C}$ and $2^{\circ} \mathrm{C}$ for the near future according to these four models. Projected differences in the lake level for the Iberá are also very different among RCMs. LMDZ, which shows the maximum increase in precipitation, also shows the greatest increment in the lake level (around $35 \mathrm{~cm}$ ). For the remaining RCMs, the VIC model predicts variations in the mean with respect to the baseline period that range between $-5 \mathrm{~cm}$ to $5 \mathrm{~cm}$ both annually and seasonally when forced with the corrected climate model data

By the end of the century (2071-2090) climate models predict an increment of the annual mean precipitation between 20 and 30\% but the uncertainty is high for the winter months with differences ranging from $-20 \%$ to $50 \%$. Annual temperature changes predicted by these models are between $2{ }^{\circ} \mathrm{C}$ and $4^{\circ} \mathrm{C}$, whereas in summer the dispersion is higher $\left(1.5^{\circ} \mathrm{C}-4.5^{\circ} \mathrm{C}\right)$. In winter, the region is also expected to be warmer by the end of the century with temperatures $2.5^{\circ} \mathrm{C}-4.5^{\circ} \mathrm{C}$ higher than for the present climate. Lake level projected changes are not higher than $20 \mathrm{~cm}$ both annually and seasonally. In JJA for PROMES these changes are negative probably due to the decrease in precipitation and the increment in temperature of more than $4^{\circ} \mathrm{C}$ which would contribute to increase evapotranspiration with the consequent decrease in the lake level. The ensemble mean of projected lake level changes considering all RCMs indicates that the increments for the near and far future in the Iberá Lake annual mean 
water level could be around $10 \mathrm{~cm}$ with the maximum rise during summer (Table 2). However, this result must be considered only as a preliminary estimation as the dispersion among the models is high particularly for the near future and the cold season.

\section{Conclusions}

The Iberá wetlands in La Plata Basin represent a unique ecosystem that is very vulnerable to changes in its hydrodynamics. This study assessed the impacts of projected climate change on the hydrology of the Iberá system using the VIC hydrology model and four RCMs from the CLARIS-LPB project.

The hydrology model was calibrated and validated with historical observed daily data and was able to satisfactorily replicate the observed lake level for the target period 1991-2000 with a correlation coefficient of 0.73. However, to assess the impacts of projected temperature and precipitation changes in water availability in the Iberá region, climate model outputs are necessary. Meteorological data from four RCMs were used as input in the VIC hydrology model, but as all climate models present systematic errors, the application of a bias correction scheme was required. In this study we applied the quantile-based mapping bias correction methodology to both monthly temperature and precipitation fields. The corrected data had better skill in the representation of the annual and seasonal means in almost all RCMs with the only exception being the RCA model vinter precipitation. This model also has the poorest representations of the observed precipitation field compared with the other RCMs.

Regarding future projections, all models are consistent in predicting a warming for both the near future and for the end of the $21^{\text {st }}$ century in the region of Iberá, but differ in the sign and percentage of change in precipitation. As a result, future water level changes highly vary among models. Despite these differences, an indication of possible changes in the lake level can be obtained when considering the average among all RCMs results. This average indicates that the llberá water level could increase during the $21^{\text {st }}$ century and that this increment would be higher in the summer months than during winter. Nevertheless, the projected $10 \mathrm{~cm}$ of water level increase could be not so relevant as it is of the same order of magnitude than the observed interdecadal variability of the system. .

In order to assess the impacts of climate change on the ecological dynamics, not only future scenarios of water levels in the wetland and lakes are important but also changes the inundation area. However, since the natural shorelines of the Iberá Lake 
are floating islands (Ferrati et al, 2005), it is expected that they will rise when water level rises maintaining the shape of the lake probably unchanged. Therefore, even having an estimation of possible changes in the lake level, future changes in the inundation area are still highly uncertain.

\section{Acknowledgements}

This research was supported by the European Community's Seventh Framework Programme (FP7/2007-2013) under Grant Agreement $N^{\circ} 212492$, the University of Buenos Aires UBACYT- 20020100100803 and 20020100300067 , Consejo Nacional de Investigaciones Científicas y Técnicas PIP2009-00444 and Agencia Nacional de Promoción Científica y Tecnológica PICT07-00400 and PICT-2012-2403. 


\section{References}

Barros VR, Chamorro L, Coronel G, Báez J. 2004. The major discharge events in the Paraguay River: magnitudes, source regions and climate forcings. Journal of Hydrometeorology, 5, 1161-1170.

Barros, V., M. Doyle, and I. Camilloni, 2008. Precipitation trends in southeastern South America: relationship with ENSO phases and with low-level circulation. Theor. Appl. Climatol., 93, 19-33.

Bischoff S., García N., Vargas W., Jones P., Conway D., 2000. Climatic variability and Uruguay River flows. Water International, 25, 446-456.

Boulanger, J-P; F .Martinez and E. Segura. 2007. Projection of future climate change conditions using IPCC simulations, neural networks and Bayesian statistics. Part 2: Precipitation mean state and seasonal cycle in South America. Clim. Dyn., 28, 255271.

Bowling, L. C. and Lettenmaier, D. P., 2010. Modeling the effects of lakes and wetlands on the water balance of arctic environments, J. Hydromet., 11, 276-295.

Camilloni, I. and V. Barros, 2003. Extreme discharge events in the Paraná River and their climate forcing. J. Hydrol., 278, 94-106.

Camilloni,I. and M.Bidegain. 2005. Escenarios climáticos para el siglo XXI. In: V.Barros, A. Menéndez y G.Nagy, eds. El Cambio Climático en el Río de la Plata. Buenos Aires, CIMA, 33-39.

Cardinali, L. M. and Chamorro, L. F., 2002. Análisis del comportamiento de niveles hidrométricos en el sistema Iberá. Report, Entidad Binacional Yacyretá.

da Rocha, R. P., C. A. Morales, S. V. Cuadra, and T. Ambrizzi, 2009: Precipitation diurnal cycle and summer climatology assessment over South America: An evaluation of Regional Climate Model version 3 simulations. J.Geophys. Res., 114:1-19. doi:10.1029/2008JD010212.

Distributed Active Archive Center, 2000. Global soil data products (IGBP-DIS). Oak Ridge National Laboratory Distributed Active Archive Center, CD-ROM. Available from: http://daac.ornl.gov/SOILS/guides/igbp.html. 
Domínguez, M., Gaertner, M.A., de Rosnay, P., Losada. T., 2010: A regional climate model simulation over West Africa: parameterization tests and analysis of land-surface fields. Clim.Dyn.,35: 249-265.

Ferrati, R., Canziani, G.A., Ruiz Moreno, D., 2005. Esteros del Ibera: Hydrometeorological and hydrological characterization. Ecological Modelling, 186 (1 SPEC. ISS.), 3-15.

Fowler, H.J., S. Blenkinsop, C. Tebaldi, 2007. Linking climate change modelling to impacts studies: Recent advances in downscaling techniques for hydrological modeling. Int. J. Climatol., 27 (12), 1547-1578. doi:10.1002/joc.1556

Gao, H., Bohn, T. J., Podest, E., McDonald, K. C., and Lettenmaier, D. P., 2011. On the causes of the shrinking of lake Chad. Env. Res. Lett. 6(034021).

Giraut, M. A., Rujana, M., and Valladares, A., 2009. El rol de los humedales en el contexto evolutivo de la red hídrica superficial de la Provincia de Corrientes, República Argentina. Aqua-LAC, 2(1),18-25.

Giorgi, F., 2002. Variability and trends of sub-continental scale surface climate in the twentieth century. part II: AOGCM simulations. Climate Dynamics, 18(8), 693-708.

Grimson R., N. Montroull, R. Saurral, P. Vasquez, I.Camilloni, 2013. Hydrologic modelling of the Iberá Wetlands in southeastern South America. J. Hydrol. In review.

Gulizia, C., I. Camilloni and M. Doyle, 2012. Identification of the principal patterns of summer moisture transport in South America and their representation by WCRP/CMIP3 global climate models. Theor. Appl. Climatol., doi:10.1007/s00704-0120729-4.

Hansen, M., R. DeFries, J. R. G. Townshend y P. Sohlberg, 2000. Global land cover classification at $1 \mathrm{~km}$ resolution using a decision tree classifier. Int. J. Remote Sensing, 21, 1331-1364.

Hay, L.E., Clark, M.P., Wilby, R.L., Gutowski, W.J., Leavesley, G.H., Pan, Z., Arritt, R.W., Takle, E.S., 2002. Use of regional climate model output for hydrologic simulations. Journal of Hydrometeorology, 3 (5), 571-590. 
Hourdin, F., Musat, I., Bony, S., Braconnot, P., and others. 2006. The LMDZ4 general circulation model: climate performance and sensitivity to parametrized physics with emphasis on tropical convection. Clim. Dyn., 27: 787-813.

Kjellström E., Bärring L., Gollvik S., Hansson U., Jones C., Samuelsson P., Rummukainen M., Ullerstig A., Willén U. and Wyser K. 2005. A 140-year simulation of European climate with the new version of the Rossby Centre regional atmospheric climate model (RCA3). Report in Meteorology and Climatology 108, SMHI, SE-60176 Norrköping, Sweden, 54 pp.

Li, Z.X., 1999: Ensemble atmospheric GCM simulation of climate interannual variability from 1979 to 1994. J. Climate, 12: 986-1001.

Liang, X., D. P. Lettenmaier, and E. F. Wood, 1996. One-dimensional statistical dynamic representation of subgrid spatial variability of precipitation in the two-layer Variable Infiltration Capacity model. J. Geophys. Res 101 (D16), 21403-21422.

Liang, X., D. P. Lettenmaier, E. F. Wood and S. J. Burges, 1994. A simple hydrologically based model of land surface water and energy fluxes for GSMs. $J$. Geophys. Res., 99 (D7), 14415-14428.

Mishra, V., Cherkauer, K. A., and Bowling, L. C., 2010. Parameterization of lakes and wetlands for energy and water balance studies in the Great Lakes region. J. Hydromet., 11(5), 1057-1082.

Mitchell, T.D, and P. Jones, 2005, An improved method of constructing a database of monthly climate observations and associated high-resolution grids. Int. J. Climatol., 25, 693-712.

Montroull, N., Saurral, R., Camilloni, I., Sörensson, A., Menéndez, C., and Ruscica, R., 2013. Escenarios hidrológicos futuros en la región de los esteros del Iberá en el contexto del cambio climático. Revista Meteorologica, in press.

Nash, J. E. y Sutcliffe, J.V., 1970. River flow forecasting through conceptual models part I: A discussion of principles. J. Hydrology, 10(3), 282-290.

Neiff, J. J., 1997. El régimen de pulsos en ríos y grandes humedales de Sudamérica. In: A. Malvárez y P. Kandus, eds. Trópicos sobre grandes humedales sudamericanos. ORCYT MAB (UNESCO), Montevideo, Uruguay, 99-149 
Pal, J. S. and Coauthors, 2007: The ITCP RegCM3 and RegCNET: Regional Climate Modeling for the Developing World. Bull. Am. Meteorol. Soc. 88(9):1395-1409.

Piani, C., \& Haerter, J. O., 2012. Two dimensional bias correction of temperature and precipitation copulas in climate models. Geophys. Res. Lett., 39(20).

Quintana Seguí, P., A. Ribes, E. Martin, F. Habets, and J. Boé. 2010. Comparison of Three Downscaling Methods in Simulating the Impact of Climate Change on the Hydrology of Mediterranean Basins. J. Hydrology, 383 (1-2),111-124.

Samuelsson P., Gollvik S. and A.Ullerstig 2006:The land-surface scheme of the Rossby Centre regional atmospheric climate model (RCA3). Reportin Meteorology 122. SMHI, SE-60176 Norrköping, Sweden, 25 pp

Sanchez, E., M. A. Gaertner, C. Gallardo, E. Padorno, A. Arribas, and M. Castro (2007): Impacts of a change in vegetation description on simulated European summer present-day and future climates. Clim. Dyn. , 29,319-332.

Santhi, C., Arnold, J.G., Williams, J.R., Dugas, W.A., Srinivasan, R. y Hauck, L.M., 2001. Validation of the SWAT Model on a Large River Basin with Point and Nonpoint Sources. J. Am. Water Resour.Assoc., 37, 1169-1188.

Saurral, R., V. Barros and D. Lettenmaier, 2008. Land use impact on the Uruguay River discharge. Geophys. Res. Lett, 35, L12401, doi:10.1029/2008GL033707.

Saurral, R. I., 2010. The hydrologic cycle of the La Plata Basin in the WCRP/CMIP3 multi-model dataset. J. Hydrometeor., 11, 1083-1102.

Saurral, R., N. Montrouli, and I. Camilloni, 2013: Development of statistically unbiased 21st century hydrology scenarios over La Plata Basin. International Journal of River Basin Management-CLARIS-LP Special Issue (Submitted).

Silvestri, G. and C.Vera. 2008. Evaluation of the WCRP-CMIP3 model simulations in the La Plata basin. Meteorol.Appl. 15, 497-502.

Solomon, S., D. Qin, M. Manning, M. Marquis, K. Averyt, M. M. B. Tignor, H. L. Miller Jr., and Z. Chen, Eds., 2007. Climate Change 2007: The Physical Science Basis. Cambridge University Press, 996.

Su, F., and D. P. Lettenmaier, 2009. Estimation of surface water budget of La Plata Basin. J. Hydrometeor., 10, 981-998. 
Teutschbein, C. and J. Seibert, 2012. Bias correction of regional climate model simulations for hydrological climate-change impact studies: Review and evaluation of different methods. J. Hydrology, 456-457, 12-29.

van Roosmalen, L., Christensen, J.H., Butts, M.B., Jensen, K.H., Refsgaard, J.C.,2010. An intercomparison of regional climate model data for hydrological impact studies in Denmark. J. Hydrology, 380 (3-4), 406-419.

Vera, C., G. Silvestri, B. Liebmann, and P. Gonzalez, 2006. Climate change scenarios for seasonal precipitation in South America from IPCC-AR4 models. Geophys. Res. Lett.,33, L13707, doi:10.1029/2006GL025759.

Vera, C., P.González and G.Silvestri, 2009. About uncertainties in WCRP/CMIP3 climate simulations over South America. In: Preprints of 9th International Conference on Southern Hemisphere Meteorology \& Oceanography, Melbourne, Australia.

Vidal, J-P and S. Wade. 2007. A framework for developing high-resolution multi-model climate projections: 21st century scenarios for the UK. Int. J. of Climatol., 28, 843-858.

Vidal, J-P and S. Wade, 2008. Multimodel projections of catchment-scale precipitation regime. J. Hydrology, 353, 143-158.

Vidal, J-P and S. Wade, 2009. A multimodel assessment of future climatological droughts in the United Kingdom. Int, J, / of Climatol., 29, 2056-2071.

Wood, E. F., Lettenmaier, D.P \& Zartarian, V.G., 1992. A Land-Surface Hydrology Parameterization with Subgrid Variability for General-Circulation Models, J. Geophys. Res.-Atmos., 97(D3), $2717-2728$.

Wood, A. W., E. P. Maurer, A. Kumar, and D. P. Lettenmaier, 2002. Long-range experimental hydrologic forecasting for the eastern United States. J. Geophys. Res., 107, 4429, doi:10.1029/2001JD000659.

Wood, A.W.; Leung Lai, R; Sridhar, V. and D Lettenmaier. 2004. Hydrologic implications of dynamical and statistical approaches to downscaling climate model outputs.Climatic Change, 62, 189-216. 


\section{Tables}

Table 1. Observed annual and seasonal precipitation ( $\mathrm{mm} / \mathrm{month}$ ) and temperature $\left({ }^{\circ} \mathrm{C}\right)$ averages for the Iberá region for the period 1991-2000

\begin{tabular}{ccc}
\hline & Precip(mm/month) & $\mathbf{T}\left({ }^{\circ} \mathrm{C}\right)$ \\
DJF & 153.5 & 26.2 \\
JJA & 63.5 & 16.1 \\
ANNUAL & 127.5 & 21.2 \\
\hline
\end{tabular}

Table 2. Ensemble mean and standard deviation of projected changes in the Iberá Lake level (cm) for two future time slices (2021-2040 and 2071-2090). Baseline is 1991-2000 for all the models except RegCM3.

\begin{tabular}{llll}
\hline & ANNUAL & DJF & JJA \\
\hline (2021-2040)-Baseline & $10(17.6)$ & $10.8(17.2)$ & $8.6(18.9)$ \\
$(2071-2090)-B a s e l i n e$ & $9.1(7.7)$ & $11.2(6.8)$ & $6.1(10)$ \\
\hline
\end{tabular}

\section{Figure Captions}

Fig. 1. Location of the Ibera wetlands (Esteros del Iberá) and Paso Lucero gauging station. Elevation is indicated in meters (shaded)

Fig 2. Annual level (black line) of the Iberá Lake at Carlos Pellegrini and 11-year running mean (grey line) for the period 1929-2011.

Fig. 3. Observed (blue) and simulated (red) daily level of the Iberá Lake at Carlos Pellegrini for the period 1991-2000.

Fig. 4. Annual (top), austral summer (December-January-February, DJF) (middle) and austral winter (June-July-August, JJA) (bottom) mean precipitation as depicted by RegCM3, PROMES, LMDZ and RCA (columns 1 to 4, respectively), and CRU observations (column 5 ). Units are $\mathrm{mm} \mathrm{month}^{-1}$. Black line indicates the lberá wetland basin. Period: 1991-2000 
Fig 5. As Figure 4 but for mean temperature in units of ${ }^{\circ} \mathrm{C}$.

Fig 6. Normalized Root Mean Square Error (NRMSE) for precipitation (top) and temperature (bottom) for bias corrected (circles) and uncorrected (cross) RCMs outputs. Annual values are in green, DJF in red and JJA in blue.

Fig 7. Annual, austral winter (JJA) and summer (DJF) precipitation (\%), temperature $\left({ }^{\circ} \mathrm{C}\right)$ and Iberá Lake level $(\mathrm{cm})$ changes for two future time slices (2021-2040 and 20712090) for individual RCMs. Baseline is $1991-2000$ for all the models except RegCM3. 


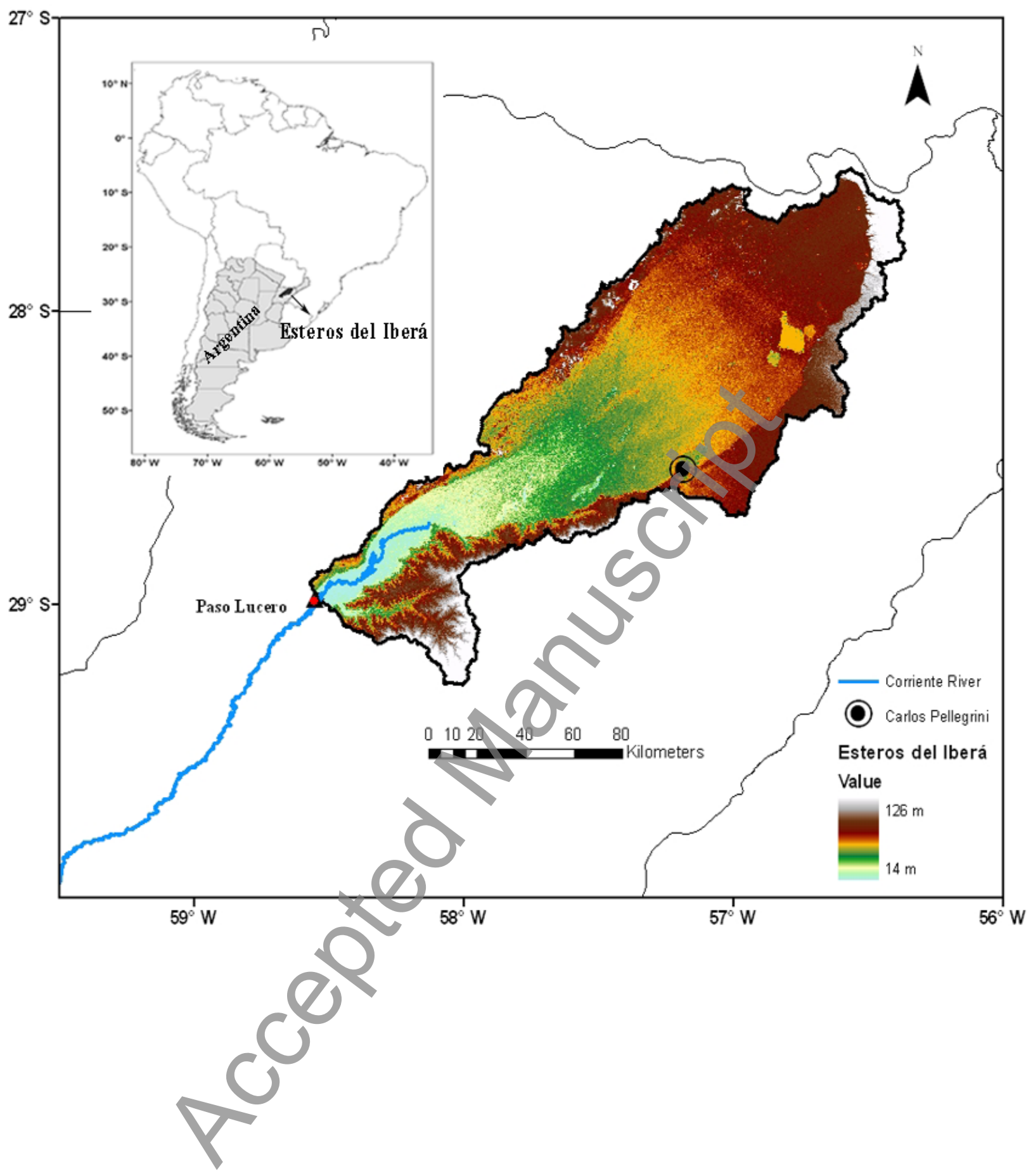



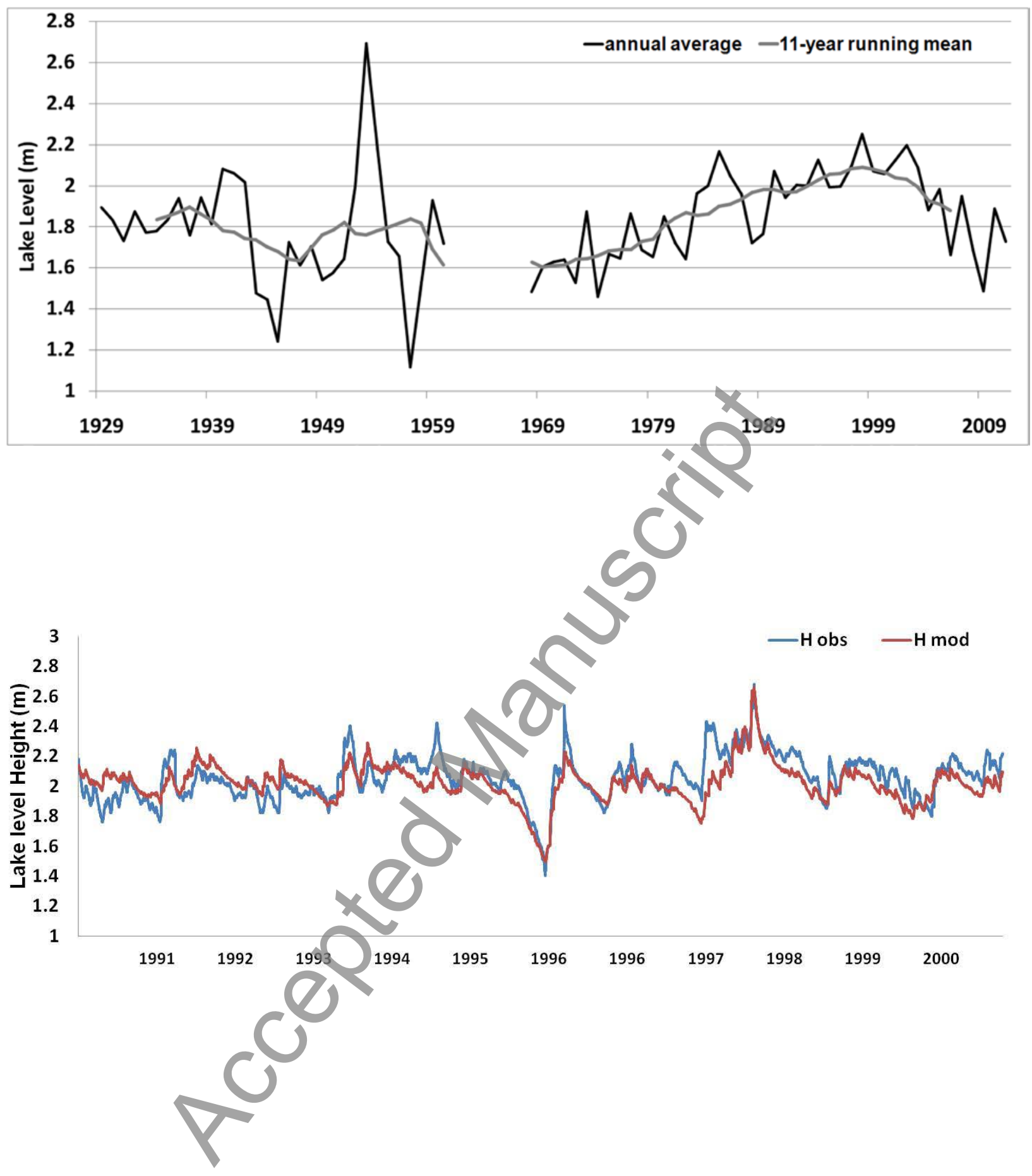

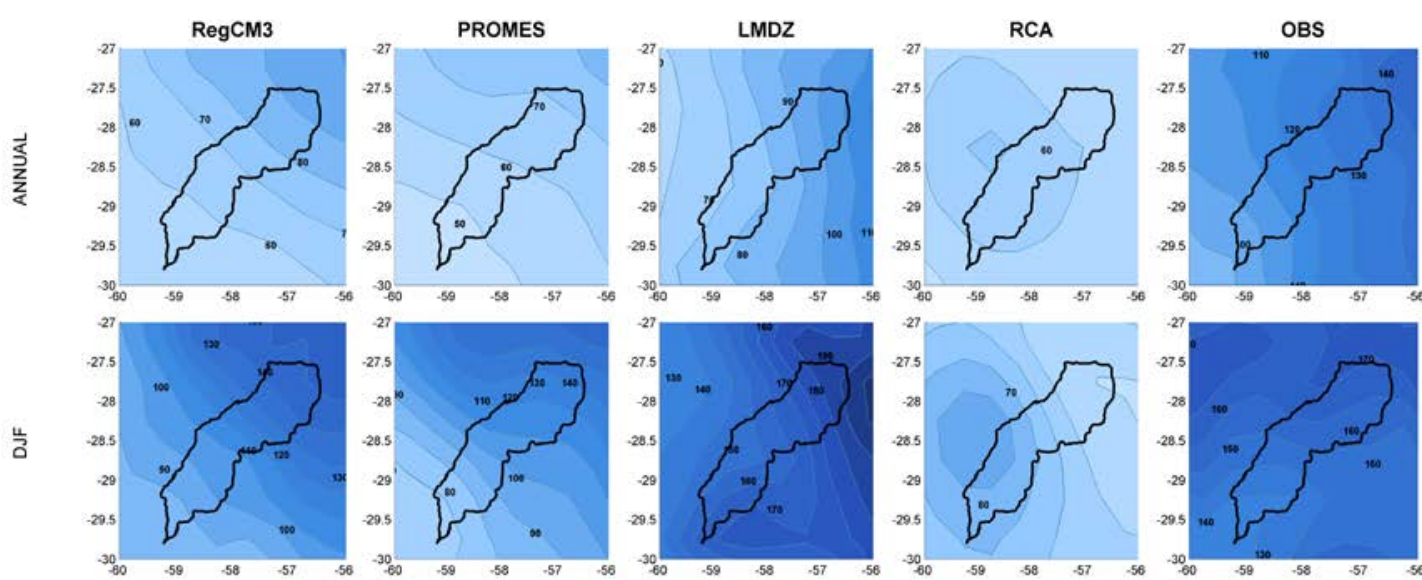

$\leftrightarrows$
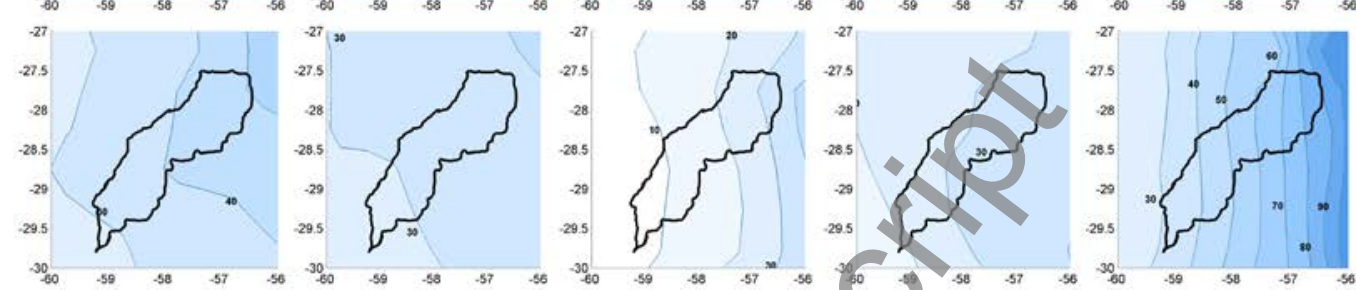

5
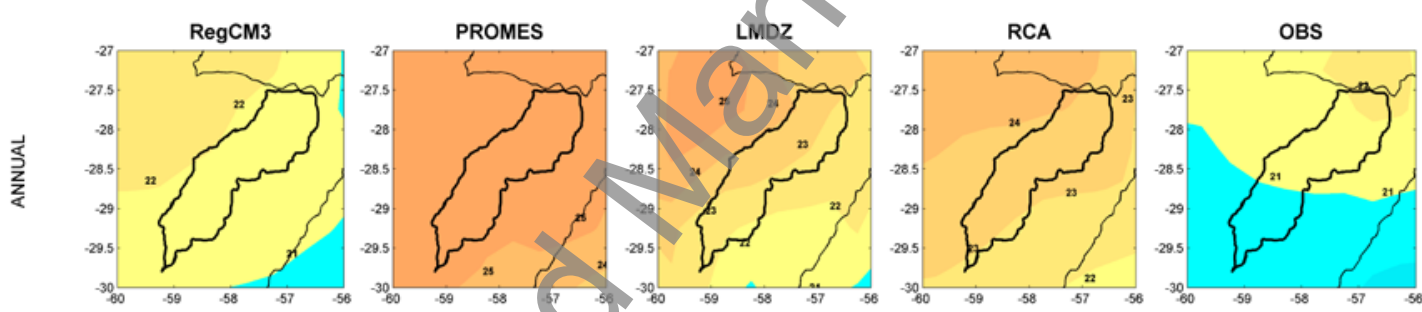

㕣
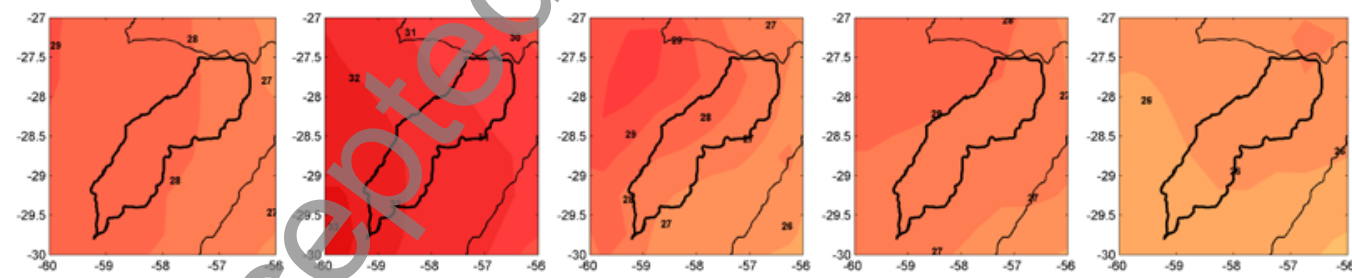

$\leftrightarrows$
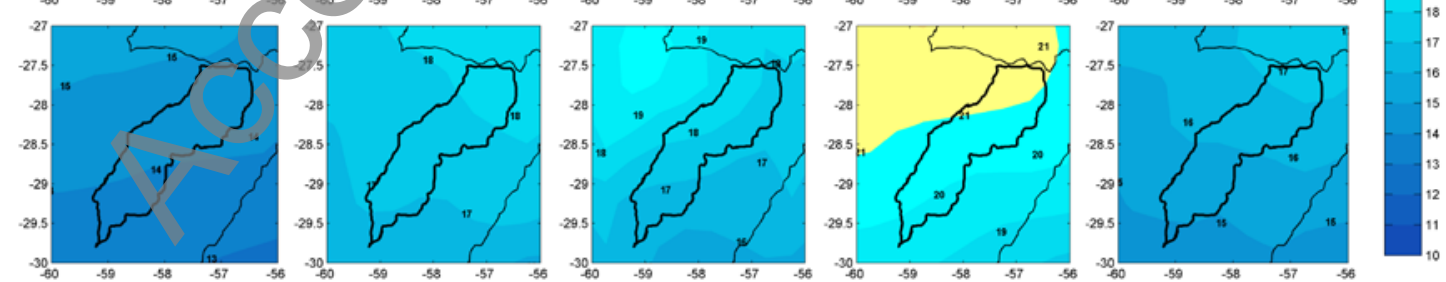

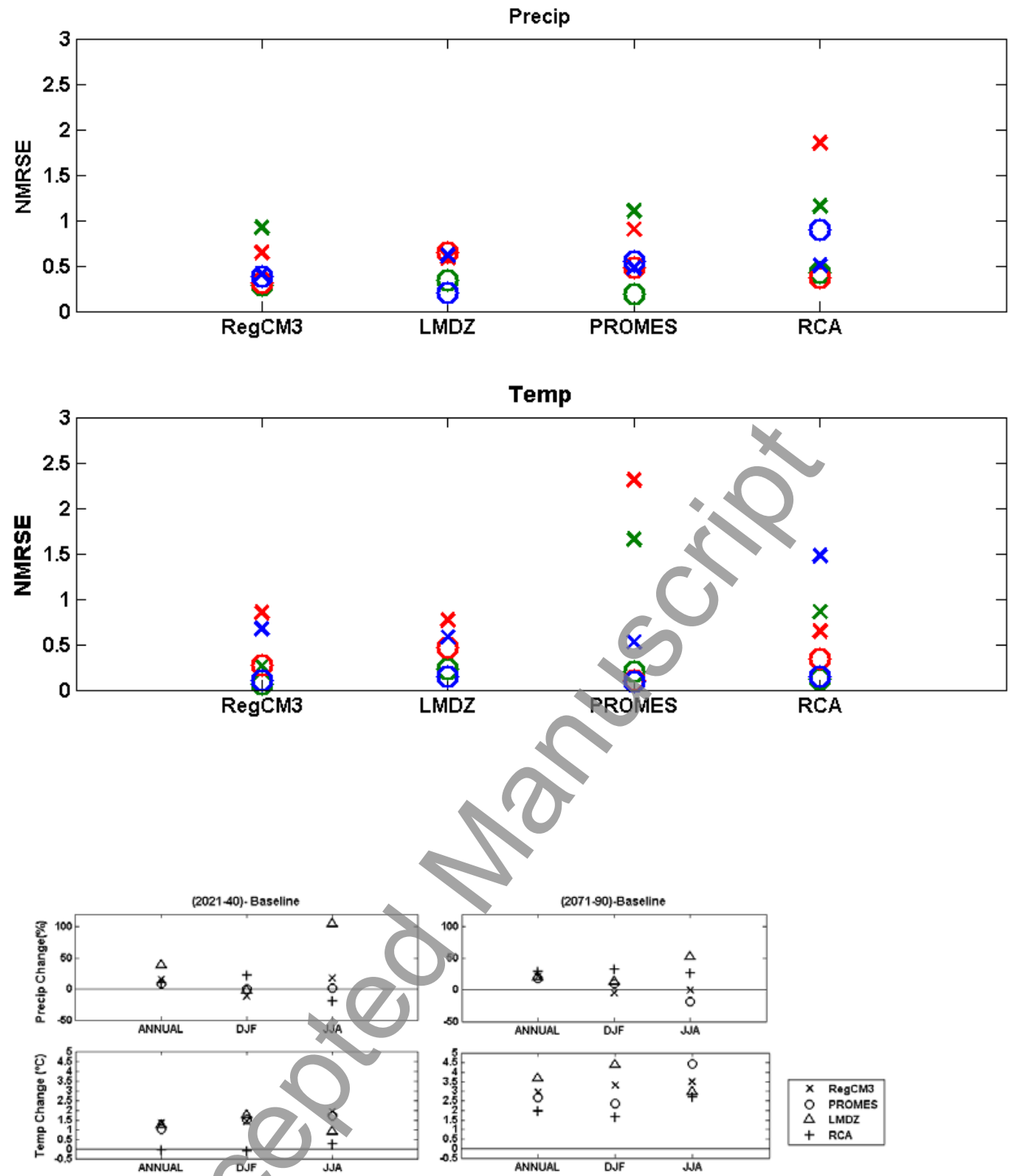

\begin{tabular}{|ll|}
$\mathbf{X}$ & RegCM3 \\
$\circ$ & PROMES \\
$\triangle$ & LMDZ \\
+ & RCA \\
\hline
\end{tabular}
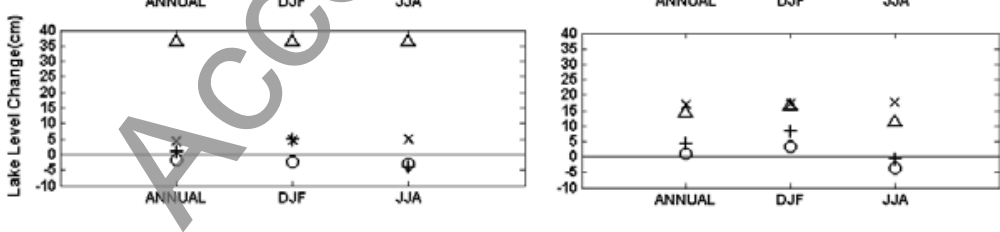
The authors would like to thank the reviewers for their time and their valuable comments that helped us to improve the manuscript.

\section{Response to comments of Reviewer 1:}

1. In the Introduction, the description of the site lacks in information on the climate and hydrology of the basin or of the wetlands and should be interested for the reader to be introduced in the climate of the case study. For instance, which is the annual discharge flowing from Iberà region to Corriente River?

\section{RESPONSE}

We included in the section 2.1 Region of study information on the climate and hydrology of the basin. A new Figure with the annual lberá Lake level for 19291991 was added.

2. In my opinion, information on the annual and seasonal values of precipitation and Temperature in the Iberà Wetland characterized the period 1991-- 2000 and used in Section 3 for comparison with future scenarios, should be added. In fact, the normalized NRMSE values as expressed in Eq. 1 are not clearly representative of the improvement in the variable corrections if information on the absolute values lacks.

\section{RESPONSE}

A new table (Table 1) was added with information on the annual and seasonal averages of observed precipitation and temperature in the lberá wetlands region for the period 1991-2000. These values correspond to those used in Eq.1 (Xobs). When comparing the corrected and the uncorrected model data for the same period (annual, JJA or DJF), Xobs is the same and therefore the NRMSE are comparable and representative of the improvement.

3. Knowing the absolute values in precipitation and temperature, please comment if the differences between future and present, as shown for all the RCMs in Figure 6, should be caused by climate changes (A1B scenario) and not by numerical discrepancies/errors of the models.

\section{RESPONSE}

An increase of $10 \%$ in precipitation in the Iberá region can be translate in 13 $\mathrm{mm} / \mathrm{month}$ of increment, which means that these results are not due to numerical errors in the model.

4. At the end of page 7, you say that the highest rise in lake water level is during the summer. How do you explain this strange result? 


\section{RESPONSE}

The inundation season is mostly in summer and the highest values of precipitation are also in the summer months. Considering the same difference in percentage of precipitation for summer and winter, the amount of water is higher for DJF and therefore the lake level rise is higher. When looking at the results of individual models, the highest precipitation increases are found in winter (JJA) along with the highest dispersion among the models. For the summer months almost all models agree that there would be an increment in the lake level and therefore the highest increments are found for the summer months.

5. Why is the water level rise in Figure 7 imposed equal to $20 \mathrm{~cm}$ ? That is the maximum value estimated by one of the RCMs, while the average value is lower as also shown in Table 1.

\section{RESPONSE}

Figure 7 was eliminated according to the comments of reviewer 2 (comment 10).

6. Please, motivate your last sentence in conclusion ("Nevertheless, the projected 1015 centimeters of water level increase...").

\section{RESPONSE}

Projected changes in the mean values of the lberá Lake have the same order of magnitude than the observed interdecadar variability mentioned in section 2.1.

7. There are editorial changes that should be implemented. In particular, Figures 5 and 6 need to be better reproduced in the text: i.e. larger labels, symbols and legend, since it is quite hard to understand what they are showing.

\section{RESPONSE}

Labels, symbols and legends have been enlarged in Figures 5 and 6 (now Figures 6 and 7).

8. Please, review the following text:

8.1 P3R11: unbiased?

8.2 P3R35: which?

8.3 P3R41: Variable Infiltration Capacity (VIC)

8.4 P3R49: successfully

8.5 P4R7: improvement in the model description

8.6 P4: explicit the variables Ws, Ds, Dsmax

8.7 P4R50: coefficient

8.8 P5R47: to be consistent to the figures, the model name is IPSL and not LMDZ.

8.9 P8R31-33: not clear and improve English.

8.10 In Fig. 2 caption, remove "forced with observations"

8.11 In Fig. 4 caption, add the temperature unit

8.12 In Fig. 7 caption, ": in blue, the present ... and in light blue..." (remove are indicated) 
8.13 In Table 1 caption: "Future-present differences in Iberà lake level: Average over the 4 RCMs"

\section{RESPONSE}

All indicated items have been corrected or clarified in the text.

9. Please, review in the text:

9.1 P2R13: Bischoff et al. 2000

9.2 P2R36: Vera et al. 2006

9.3 P2R45: Fowler et al.2007

9.4 P3R2: van Roosmalen et al. 2010, change position of Piani and Haerter in the bibliography list

9.5 P3R36: Cardinali

9.6 P3R52: Su and Lettenmaier 2009

RESPONSE

The bibliography has been revised as indicated.

\section{Response to comments of Reviewer 2:}

1. Based on the output obtained from four RCMs used to drive the VIC hydrological model, the authors derive future changes in temperature, precipitation and water levels in the Iberá wetlands located in Argentina

One question that immediately comes up is why the authors have used a 10-year meteorological data series to calibrate de RCMs. Long-term climate projections require a much longer calibration series, at least 20 years, in order to be reliable. The chosen period (1991-2000) has an extraordinary precipitation event in 1998 that caused flooding in the region and so such a short time series doesn't seem typical. It's not clear why the authors haven't used a 20 -year or, even better, a 30-year series. In page 5 they say that present climate was considered as the period 1991-2000 for all the RCMs except for RegCM3 where the period used as present was 1981-1990. Why was this done?

\section{RESPONSE:}

For the calibration of the VIC hydrology model we choose the period 1990-1997 because we had a maximum amount of meteorological data available with a minimum of missing data over the lberá region compared with other periods . The VIC model showed to have a good performance for 1998 which was a year with an extraordinary flooding event even though it was not calibrated in that year.

We considered the present climate in RegCM3 as 1981-1990 and not 1991-2000 because the data for that period was not available at the time we made this study.

This paper was done in the context of the CLARIS-LPB Project, where many RCMs were calibrated and adjusted for La Plata Basin. The period selected for 
the RCMs simulations (present climate and future time slices) was agreed among the modelling groups participating in the project

2. Since the Ibera wetland is an isolated region, meteorological stations are most probably located in its periphery but it is not mentioned how far from it or how many. The authors do not mention the distribution of the meteorological stations from which the data has been retrieved nor if it adequately reflects what is going on in the region.

\section{RESPONSE}

Meteorological stations within or close to the study region were considered in the analysis (see Figure below). The number of available records for each variable is 48 for temperature and 27 for precipitation. Details regarding the calibration of the VIC model to the Iberá region, can be found in Grimson et al 2013. 


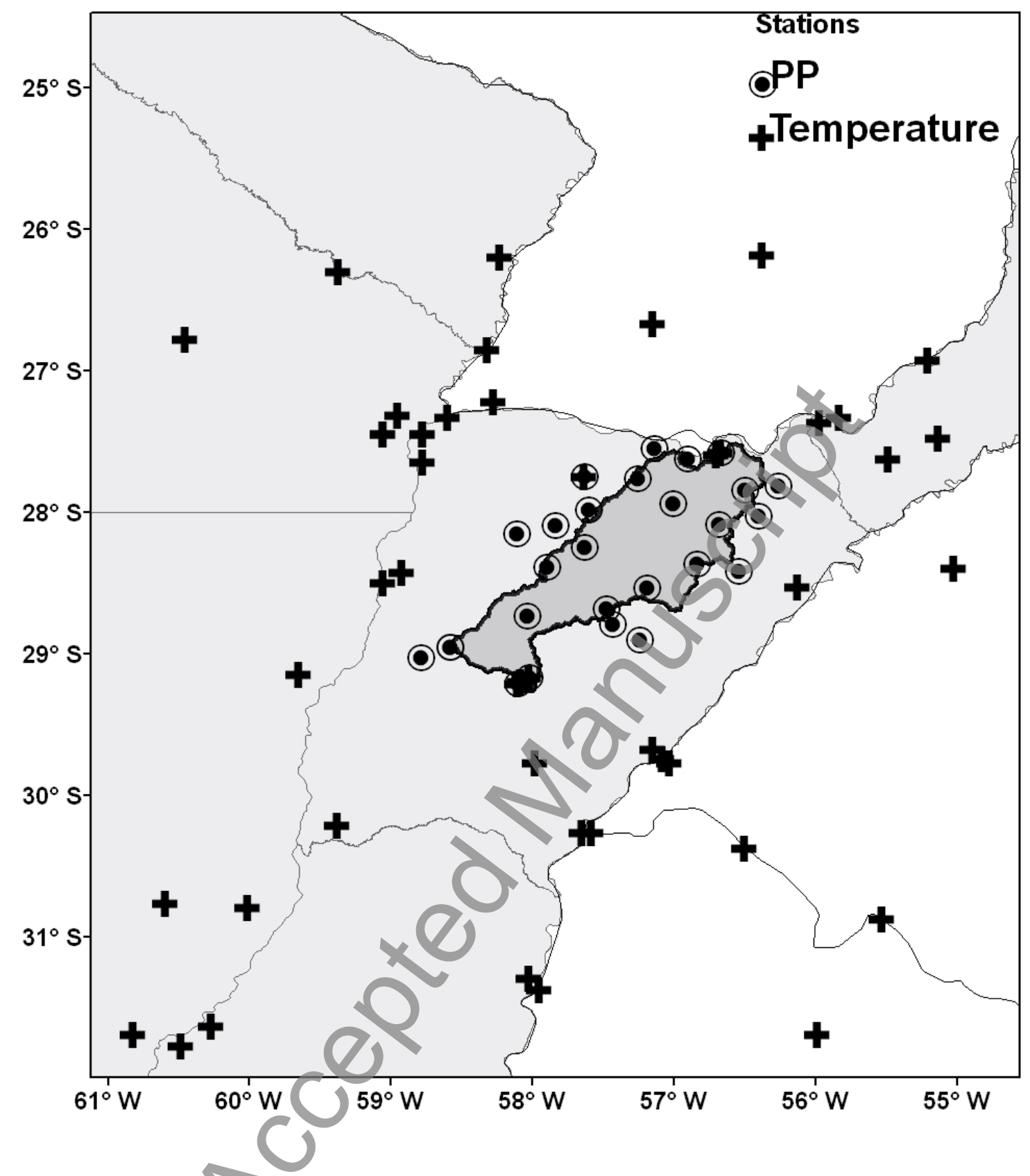

3. For adjusting soil and lake parameters, they restrict the time series to the period 1990-97 (why not 1990-2000). Among the soil variables, they mention the estimated thickness of the second and third soil layer but it is not clear if they take into account what is mentioned in one of their references (Ferrati et al. 2005) about the complexity of the geomorphological structure, leading to regions of a high index of impermeability and water surface accumulation, and other regions of characteristic predominantly entisolic soils - semi-permanently flooded - which are highly permeable allowing an underground flow. Apparently these structural differences allow the identification of three subsystems exhibiting different behaviours. 


\section{RESPONSE}

For adjusting soil and lake parameters we use the period 1990-97 because we had more meteorological data availability (see response of comment 2).

The hydrology model presented in this paper is a simplification of the Iberá system. Despite not accounting for underground flow, the VIC model represents with a good approximation the variability of the wetland from daily to decadal scales.

4. In page 5, the authors say: "The hydrological projections were made under the assumption that vegetation and the geomorphology of the Iberá Wetlands will remain unchanged." However, in page 2, they claim that "Climate variability and change could modify the Iberá Wetlands hydrological conditions and consequently affect its biodiversity", and in page 8 they say that the wetlands "represent a unique ecosystem that is very vulnerable to changes in its hydrodynamics." So the assumption that the vegetation will remain unchanged needs some extra arguments for support.

\section{RESPONSE}

The hydrological projections were made under the assumption that vegetation and the geomorphology of the Iberá wetlands will remain unchanged as there are no scenarios of possible vegetation changes available for this region.

5. The systematic averaging of morphological and hydrological data, considering the wetland as one large homogeneous pool seems to be masking the wetland dynamics which appears to be quite complex and might have an effect on the actual long-term balance.

\section{RESPONSE}

VIC model is not yet complex enough to consider the wetland as a mosaic divided into several grid cells allowing taking into account variations of temperature, precipitation and geomorphology of the Iberá wetland. However, we found that VIC model satisfactorily represents the level of the Iberá Lake at daily scales, even though there is a simplification of the system.

6. The authors do not mention, or I haven't been able to find anything, even implicit, about the extension of the study area for running the RCMs and how they avoid the border effects that may affect the physics in the models in their simulations. Are the RCMs run over the study area shown in Figures 3 and 4? I understand that the models should run over a much larger area. How was the downscaling done? How does the climatology of the models relate to the observed atmospheric circulation for the interval 1990-2000?

Authors don't include any critical comments on the reasons for the differences of the RCMs output nor on the bias or "error" regarding the present climate, and/or if there is any connection to having used a 10-year series for calibrating the models. Why does one model overestimates and the other underestimates the variables? Differences of 2 to 7 degrees in the temperature predictions over a decade seem high. Even after bias correction, how reliable are the long-term predictions? Are there any confidence intervals? 


\section{RESPONSE}

All RCMs were run for the same domain that includes all South America at $50 \mathrm{~km}$ resolution (for more details see Solman, S.; E. Sanchez, P. Samuelsson,R. da Rocha, L. Li, J.Marengo, N. Pessacg, A.R.C. Remedio, S. C. Chou, H. Berbery, H. LeTreut, M. de Castro and D. Jacob; (2012). Evaluation of an ensemble of regional climate model simulations over South America driven by the ERAInterim reanalysis: Model performance and uncertainties. Climate Dynamics). It was out of the scope of this study to validate the performance of the climate models out of the region of the lberá wetlands or to make an evaluation of the dynamical of each model and the reasons of the better o poorer representation of the observed climate. We made a validation of the RCMs in our study area and showed that the climate models have difficulties in representing the present climate and therefore a bias correction is needed before using this data for hydrologic projections. Climate models are the best tools that the community has to understand and project climate change and the methodology used in this paper to evaluate hydrological variations at a basin level due to climate change is widely used and accepted throughout the scientific community.

7. I don't believe that averaging the output of several models when they show discrepancies in the predictions improves the assessment. It only adds to the errors.

\section{RESPONSE}

We used the average of the changes in the lake level in order to determine a possible future scenario considering the RCMI used in this paper. However, it is true that there is uncertainty in these results as can be seen in Figure 7. As additional information we add to Table 2 the standard deviation of the models' outputs.

8. There are basically no comments on the performance of the VIC model. The authors say that for the period (2021-2041) "The VIC model predicts variations that range between $-5 \mathrm{~cm}$ to $5 \mathrm{~cm}$ both annually and seasonally when forced with the corrected data from the remaining RCMs". However the data series on the observed water level dynamics of the lbera shallow lake at Carlos Pellegrini (Figure 2) shows that the annual and seasonal averages can be much higher.

\section{RESPONSE}

The variation in the mean lake level between the future and the present decade should be compared with the interdecadal variability of the Iberá system which is of about $14 \mathrm{~cm}$ and not with the variation shown in Figure 2 (now Figure 3) that shows the daily values. It is true that $5 \mathrm{~cm}$ of change is within the variability of the system, but the "no change" of the lake level is also a result of the model.

9. For the projections over the period (2071-2090) the authors say that "Lake level differences projections are not higher than $20 \mathrm{~cm}$." Are they referring to annual averages? 


\section{RESPONSE}

We change the sentence "Lake level differences projections are not higher than $20 \mathrm{~cm}$ " for "Lake level differences projections are not higher than $20 \mathrm{~cm}$ both annually and seasonally"

10. The first paragraph in page 8 doesn't make any sense at all. The lbera system is mostly permanently flooded. Ferrati el al (2005) say that "More than $70 \%$ of its surface is permanent or temporarily flooded, yielding a fluctuant stage that oscillates up to $1 \mathrm{~m}$ in depth. This wetland is characterized by a deficient superficial drainage and a slow movement of masses of water, regulated by biotic effects." Particularly regarding the Eastern or oriental subsystem, "The highest depths are observed in the eastern border, on the ancient drainage bed Parana-Mirinay, where the biggest permanent shallow lakes are located: Conte, Luna, Galarza, Naranjito, and Ibera. (...) These shallow lakes are connected with the contiguous marshland, but maintain their form because they are deeper and are bordered by dammedlands (embalsados)." In fact, the shallow lakes are part of the permanently flooded subsystem. As a side comment, the word "dammedlands" is a bad translation; should be "floating islands".

The authors should note that Van Duzer points out that these Neotropical inland wetlands have a singular characteristic: floating islands, locally known as "embalsados", compose the shoreline and the surrounding environment of the freewater bodies. See: Van Duzer, C. (2007). Floating Islands: A Global Bibliography. Cantor Press. California. ISBN 0-9755424-0-0. This means that when water levels rise, the floating islands will also rise and the shapes of the free-water bodies remain unchanged. Hence, it doesn't make sense to predict inundation areas around the shallow lakes because the whole oriental subsystem is already inundated and their shape won't vary.

\section{RESPONSE}

We agree with the reviewer that it is difficult to project an inundation area of the Iberá Lake, so we eliminated Figure 7 in order to avoid confusion and clarify this point in the Conclusions section.

\section{Some additional comments:}

The word "lagoon" is derived from the Italian word "laguna", which refers to the waters around Venice. As found in the commonly accessible Wikipedia, a "lagoon" is a shallow body of water separated from a larger body of water by barrier islands or reefs. Lagoons are usually divided into coastal lagoons and atoll lagoons, but they have also been identified as occurring on mixed-sand and gravel coastlines. Often in Latin America, the word "laguna", which lagoon seems to translate to, is used to describe a shallow lake. Even if sometimes freshwater bodies have been included in the definition of "lagoon", most often the term "lagoon" is restricted to bodies of water with some degree of salinity. Thus I recommend that the authors refer to these free-water bodies in the inland wetland as "shallow lakes".

\section{RESPONSE}

\section{We changed lagoon for lake.}

12 The authors refer to the large basin as "La Plata basin", but in the literature and the web the usual name given to it is "Rio de la Plata basin", or the "Del Plata 
basin". Perhaps they should adopt one of these in order to avoid generating confusions.

\section{RESPONSE}

In this special issue of this particular basin we agreed to name it as "La Plata basin".

13. In the Introduction, the authors say that the Ibera wetlands are one of the "largest continuous freshwater wetlands in South America", and in the next paragraph they mention that the RCMs spatial resolution still exceeds the scale of "small watersheds such as the Iberá Wetlands". I suggest that they make explicit the relative nature of these statements.

\section{RESPONSE}

We change the statement "However, RCMs spatial resolution still exceeds the scale of small watershed such as the Iberá Wetlands" for "However, RCMs spatial resolution still exceeds the scale of a watershed such as the lberá wetlands"

\section{Response to comments of Associate Editor}

Comments to the Author:

Albeit the second reviewer is pretty critic, the work is well written and consistent with the objective to give practical indications for la Plata Basin stakeholders.

Some well tested and accepted models were applied to forecast long term trends in precipitation, temperature and level at the Ibera wetlands. This approach has limitations and yields deviations because of the current state of the art in climate models rather than lack of knowledge in the specific case study.

My suggestion is therefore a minor revision to adjust the manuscript text following the indications of reviewers and/or answering to their criticism where appropriate.

I also recommend to make sure that figure fonts and marks can be read in the journal format, in particular they appear pretty small in figures 5 and 6.

RESPONSE

We change figure fonts and marks in Figures 5 and 6 (now Figures 6 and 7) 